\title{
APLIKASI FUZZY INFERENCE SYSTEM (FIS) METODE SUGENO DALAM MENENTUKAN KEBUTUHAN ENERGI DAN PROTEIN PADA BALITA
}

\author{
Rosida Wachdani, Zainal Abidin, M. Ainul Yaqin \\ Program Studi Teknik Informatika, \\ Fakultas Sains dan Teknologi, Universitas Islam Negeri Maulana Malik Ibrahim Malang \\ J1 Gajayana No 50 Malang 65144 Telp/Fax (0341) 558933 \\ Email: red_rocy@yahoo.co.id
}

\begin{abstract}
Abstrak - Masa balita merupakan periode perkembangan yang rentan terhadap masalah gizi. Energi dan protein yang tidak seimbang dalam menu makanan balita dapat menyebabkan malnutrisi (gizi salah). Oleh karena itu, pemenuhan energi dan protein merupakan faktor yang perlu diperhatikan dalam menjaga kesehatan balita yang sedang mengalami masa pertumbuhan dan perkembangan. Pada penelitian ini, dibangun perangkat lunak yang dapat memudahkan seseorang dalam menentukan kebutuhan energi dan protein untuk balita usia 36-59 bulan. Metode yang digunakan dalam pengembangan perangkat lunak adalah fuzzy sugeno, yaitu aturan yang direpresentasikan dalam bentuk IF-THEN dengan output berupa konstanta untuk melakukan perhitungan terhadap kebutuhan energi dan protein. Sedangkan input yang digunakan dalam metode fuzzy sugeno meliputi berat badan, tinggi badan, umur dan jenis kelamin. Pengujian terhadap fuzzy sugeno tersebut menunjukkan bahwa nilai yang dihasilkan metode ini memiliki analisis kebenaran dengan standard ideal sebesar 58\% dalam menentukan kebutuhan energi dan $86 \%$ dalam menentukan kebutuhan protein. Sedangkan metode manual memiliki analisis kebenaran dengan standard ideal sebesar $24 \%$ dalam menentukan kebutuhan energi dan $34 \%$ dalam menentukan kebutuhan protein.
\end{abstract}

Kata kunci : balita, gizi, kebutuhan energi, kebutuhan protein, fuzzy sugeno.

\section{PENDAHULUAN}

Status Gizi adalah keadaan tubuh sebagai akibat konsumsi makanan dan penggunaan zat-zat gizi (Almatsier, 2004: 285). Konsumsi makanan yang mengandung energi dan protein yang tidak sesuai dengan kebutuhan tubuh akan menyebabkan balita mengalami malnutrisi atau gizi salah. Malnutrisi yang terjadi dalam waktu yang lama akan menyebabkan balita mengalami gangguan terhadap pertumbuhan fisik dan mental.

Berdasarkan dari latar belakang tersebut maka dibuatlah perangkat lunak dengan menggunakan sistem inferensi fuzzy metode sugeno yang dapat membantu dalam menentukan kebutuhan energi dan protein yang tepat untuk memperoleh status gizi seimbang pada balita. Metode ini merupakan aturan fuzzy berbentuk if antenseden then konsekuen, di mana konsekuen berupa persamaan linear untuk menghitung jumlah 
kalori dan protein yang dibutuhkan tubuh balita setiap harinya.

\section{TINJAUAN PUSTAKA \\ 2.1 Status Gizi}

Status Gizi dibedakan antara status gizi buruk, gizi kurang, gizi baik dan gizi lebih. Data baku WHO-NCHS menyajikan pengukuran status gizi dalam 2 versi, yaitu persentil dan z-score. Gizi anak-anak di negara yang populasinya relatif baik (wellnourished) sebaiknya menggunakan persentil, sedangkan dinegara untuk anakanak yang populasinya relatif kurang menggunakan skor simpang baku (z-score) (Waterlow dalam Ali, 2008:4). Di Indonesia, pengukuran status gizi balita lebih banyak menerapkan z-score. Klasifikasi Status Gizi Anak Balita Menurut Standar WHO-NCHS dengan skor simpangan baku (z-score) dapat dilihat pada Tabel 1.

Tabel 1. Klasifikasi gizi menurut WHO NCHS

\begin{tabular}{|l|l|l|}
\hline Indikator & \multicolumn{1}{|c|}{ Status Gizi } & \multicolumn{1}{|c|}{ Keterangan } \\
\hline Berat & Gizi Lebih & $>2$ SD \\
Badan & Gizi Baik & $\geq-2$ SD sampai 2 SD \\
menurut & Gizi Kurang & $<-2$ SD sampai $\geq-3$ SD \\
Umur & Gizi Buruk & $<-3$ SD \\
(BB/U) & & \\
\hline Tinggi & Jangkung & $>2$ SD \\
Badan & Normal & $\geq-2$ SD sampai 2 SD \\
menurut & Pendek & $<-2$ SD sampai $\geq-3$ SD \\
Umur & Sangat Pendek & $<-3$ SD \\
(TB/U) & & \\
\hline $\begin{array}{l}\text { Berat } \\
\text { Badan }\end{array}$ & Gemuk & $>2$ SD \\
menurut & Kurmal & $\geq-2$ SD sampai 2 SD \\
Tinggi & Kurus Sekali & $<-2$ SD sampai $\geq-3$ SD \\
Badan & $<D$ \\
(BB/TB) & \multicolumn{2}{|l}{} \\
\hline
\end{tabular}

Rumus untuk menentukan z-score yaitu:

$$
z-\text { score }=\frac{\text { NIS }- \text { MMBR }}{\text { NSBR }}
$$

Dimana

NIS : Nilai Individual Subjek

NMBR : Nilai Median Baku Rujukan

NSBR : Nilai Simpang Baku Rujukan

1. Bila "Nilai Riil" hasil pengukuran $B B / U$, TB/U, BB/TB nilainya lebih besar atau sama dengan nilai median, maka:

$$
z-\text { score }=\frac{\text { Wilai Riill }- \text { Willai Median }}{\text { SD Wpp }}
$$

2. Bila "Nilai Riil" hasil pengukuran $B B / U$, TB/U, BB/TB nilainya lebih kecil dari nilai median, maka:

$$
z-\text { score }=\frac{\text { Wilai Rirl }- \text { Wilai Median }}{\text { SD Low }}
$$

\subsection{Kebutuhan Energi}

Kebutuhan energi seseorang menurut FAO/WHO (1985) adalah konsumsi energi yang berasal dari makanan yang diperlukan untuk menutupi pengeluaran energi seseorang bila ia mempunyai ukuran dan komposisi tubuh dengan tingkat aktivitas fisik yang dibutuhkan secara sosial dan ekonomi (Alamatsier, 2004:285). Energi dalam tubuh manusia dapat timbul karena adanya pembakaran karbohidrat, protein dan lemak. Dengan demikian agar manusia selalu tercukupi energinya diperlukan konsumsi makanan yang mengandung keseimbangan zat-zat gizi sesuai dengan kebutuhan tubuhnya. Kebutuhan energi anak usia 1-9 tahun untuk setiap kilogram berat badannya dapat dilihat pada Tabel 2 . 
Tabel 2 Kebutuhan energi (Kkal/Kg BB/ hari)

\begin{tabular}{|c|r|r|}
\hline $\begin{array}{c}\text { Umur } \\
\text { (Tahun) }\end{array}$ & $\begin{array}{c}\text { FAO } \\
\text { (1971) }\end{array}$ & Nelson (1969) \\
\hline $0-1$ & 112 & 110 \\
$1-3$ & 101 & 100 \\
$4-6$ & 91 & 90 \\
$7-9$ & 78 & 80 \\
\hline
\end{tabular}

Tabel 3 Kebutuhan protein harian

\begin{tabular}{|c|c|c|}
\hline $\begin{array}{c}\text { Umur } \\
\text { (Tahun) }\end{array}$ & $\begin{array}{c}\text { Kecukupan } \\
\text { Diit Indonesia } \\
\text { (gr/Kg/hari) }\end{array}$ & $\begin{array}{c}\text { Kecukupan } \\
\text { Untuk Penderita } \\
\text { KKP dan Infeksi } \\
\text { (gr/Kg/hari) }\end{array}$ \\
\hline $3-4$ & 1.84 & 2.05 \\
\hline $4-5$ & 1.79 & 2.03 \\
\hline
\end{tabular}

\subsection{Kebutuhan Protein}

Bagi balita, protein merupakan zat gizi yang sangat penting untuk proses pertumbuhan dan perkembangan balita. Kebutuhan protein pada balita lebih besar bila dibandingkan dengan kebutuhan orang dewasa karena balita sedang dalam masa pertumbuhan dan pembentukan jaringan baru yang terjadi secara besar-besaran. Kebutuhan balita terhadap protein dapat dilihat pada Tabel 3.

\subsection{Fuzzy Sugeno}

Fuzzy metode sugeno merupakan metode inferensi fuzzy untuk aturan yang direpresentasikan dalam bentuk $I F-T H E N$, dimana output (konsekuen) sistem tidak berupa himpunan fuzzy, melainkan berupa konstanta atau persamaan linear (Kusumadewi, 2002:98). Metode ini diperkenalkan oleh Takagi-Sugeno Kang pada tahun 1985. Model Sugeno menggunakan fungsi keanggotaan Singleton yaitu fungsi keanggotaan yang memiliki derajat keanggotaan 1 pada suatu nilai crisp tunggal dan 0 pada nilai crisp yang lain.

a. Model Fuzzy Sugeno Orde-Nol
Secara umum bentuk model fuzzy Sugeno Orde Nol adalah

$$
\begin{aligned}
& \text { IF }(x 1 \text { is } A 1) \circ(x 2 \text { is } A 2) \circ \ldots \circ(x N \text { is } A N) \\
& \text { THEN } z=k
\end{aligned}
$$

Dengan $A_{i}$ adalah himpunan fuzzy ke-I sebagai antenseden dan $\mathrm{k}$ adalah suatu konstanta sebagai konsekuen.

b. Model Fuzzy Sugeno Orde-Satu

Secara umum bentuk model fuzzy Sugeno Orde-Satu adalah

$$
\begin{gathered}
\text { IF } x 1 \text { is } A 1) \circ(x 2 \text { is } A 2) \circ \ldots \circ(x N \text { is } A N) \text { THEN } z \\
=p 1 * x 1+p 2 * x 2+\ldots+p N * x N+q(5)
\end{gathered}
$$

Dengan $A_{i}$ adalah himpunan fuzzy ke-I sebagai antenseden dan $\mathrm{p}_{\mathrm{i}}$ adalah suatu konstanta ke i dan q juga merupakan konstanta dalam konsekuen

\section{METODE PENELITIAN}

Pada penelitian ini, data yang digunakan sebagai input meliputi berat badan, tinggi badan, umur dan jenis kelamin. Data-data tersebut akan diolah sistem inferensi fuzzy metode sugeno untuk menghasilkan jumlah energi dan protein yang dibutuhkan tubuh balita.

\subsection{Variabel dan Himpunan Fuzzy}

Variabel yang digunakan dalam menentukan kebutuhan energi dan protein balita yaitu berat badan menurut umur $(\mathrm{BB} / \mathrm{U})$, tinggi badan menurut umur $(\mathrm{TB} / \mathrm{U})$ dan berat badan menurut tinggi badan $(\mathrm{BB} / \mathrm{TB})$. Ketiga variabel ini berdasarkan indikator yang sering digunakan dalam menentukan status gizi balita, sedangkan himpunan yang terdapat pada setiap variabel merupakan klasifikasi status gizi sesuai dengan standar WHO NCHS. Himpunan fuzzy untuk setiap variabel dapat dilihat pada Gambar 1, 2 dan 3. 


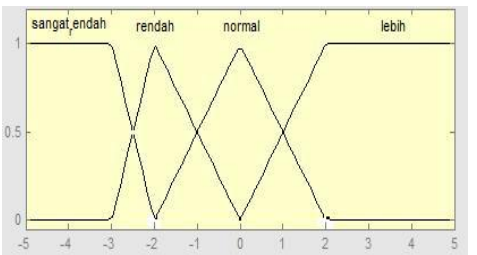

Gambar 1 Himpunan fuzzy pada variabel $\mathrm{BB} / \mathrm{U}$

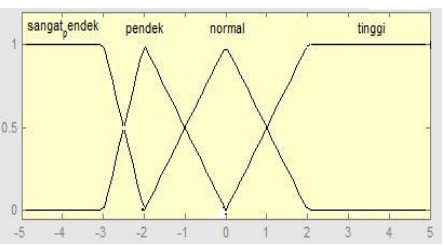

Gambar 2 Himpunan fuzzy pada variabel $\mathrm{TB} / \mathrm{U}$

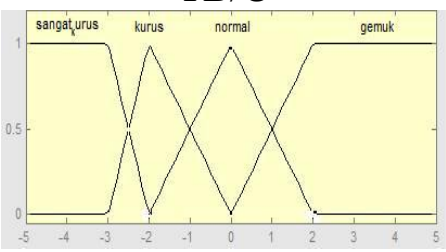

Gambar 3 Himpunan fuzzy pada variabel $\mathrm{BB} / \mathrm{TB}$

\subsection{Aturan Fuzzy}

Fuzzy terdiri dari 19 aturan untuk menentukan kebutuhan energi dan protein dalam memperoleh status gizi normal. Aturan tersebut diperoleh dari hasil percobaan terhadap 16 data baku WHO yang dipilih secara acak. Tujuan percobaan adalah untuk mengetahui hubungan yang terjadi antara berat badan menurut umur $(\mathrm{BB} / \mathrm{U})$, tinggi badan menurut umur $(\mathrm{TB} / \mathrm{U})$ dan berat badan menurut tinggi badan (BB/TB) dalam memperoleh status gizi. Percobaan untuk menentukan hubungan antara $\mathrm{BB} / \mathrm{U}$, TB/U dan BB/TB dapat dilihat pada Tabel 4, sedangkan aturan-aturan fuzzy dapat dilihat pada Tabel 5.

Tabel 4. Kesimpulan hubungan $\mathrm{BB} / \mathrm{U}, \mathrm{TB} / \mathrm{U}$ dan $\mathrm{BB} / \mathrm{TB}$ dari hasil percobaan

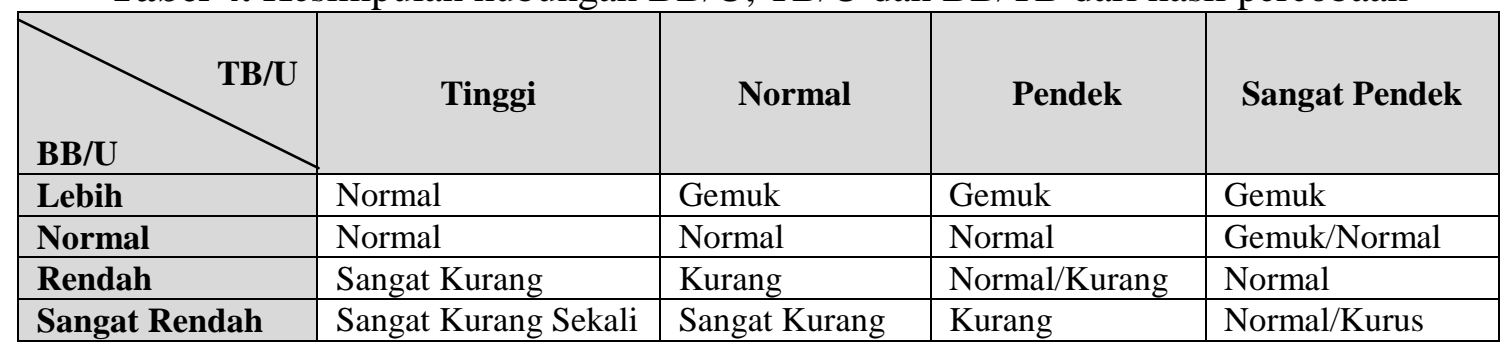

Tabel 5. Aturan Fuzzy

\begin{tabular}{|l|l|l|r|l|}
\hline \multirow{2}{*}{ Kode } & \multicolumn{1}{|c|}{ Aturan } & \multicolumn{3}{c|}{ Konsekuen } \\
\cline { 3 - 5 } & & $\begin{array}{l}\text { Rumus } \\
\text { Energi }\end{array}$ & $\begin{array}{l}\text { Tambahan } \\
\text { Energi }\end{array}$ & Rumus Protein \\
\hline$[R 1]$ & $\begin{array}{l}\text { if BB/U Lebih and TB/U Jangkung and BB/TB Normal } \\
\text { then }\end{array}$ & Nelson & $-20 \%$ & $\begin{array}{l}\text { Kecukupan Diit } \\
\text { Protein }\end{array}$ \\
\hline$[R 2]$ & $\begin{array}{l}\text { if BB/U Lebih and TB/U Normal and BB/TB Gemuk } \\
\text { then }\end{array}$ & Nelson & $-10 \%$ & $\begin{array}{l}\text { Kecukupan Diit } \\
\text { Protein }\end{array}$ \\
\hline$[R 3]$ & $\begin{array}{l}\text { if BB/U Lebih and TB/U Pendek and BB/TB Gemuk } \\
\text { then }\end{array}$ & Nelson & $-10 \%$ & $\begin{array}{l}\text { Kecukupan Diit } \\
\text { Protein }\end{array}$ \\
\hline$[R 4]$ & $\begin{array}{l}\text { if BB/U Lebih and TB/U Sangat Pendek and BB/TB } \\
\text { Gemuk then }\end{array}$ & Nelson & $-20 \%$ & $\begin{array}{l}\text { Kecukupan Diit } \\
\text { Protein }\end{array}$ \\
\hline$[R 5]$ & $\begin{array}{l}\text { if BB/U Normal and TB/U Jangkung and BB/TB } \\
\text { Normal then }\end{array}$ & Nelson & $\begin{array}{l}\text { Kecukupan Diit } \\
\text { Protein }\end{array}$ \\
\hline
\end{tabular}




\begin{tabular}{|c|c|c|c|c|}
\hline \multirow[b]{2}{*}{ Kode } & \multirow[b]{2}{*}{ Aturan } & \multicolumn{3}{|c|}{ Konsekuen } \\
\hline & & $\begin{array}{l}\text { Rumus } \\
\text { Energi }\end{array}$ & $\begin{array}{l}\text { Tambahan } \\
\text { Energi }\end{array}$ & Rumus Protein \\
\hline [R6] & $\begin{array}{l}\text { if BB/U Normal and TB/U Normal and BB/TB Normal } \\
\text { then }\end{array}$ & Nelson & 0 & $\begin{array}{l}\text { Kecukupan Diit } \\
\text { Protein }\end{array}$ \\
\hline [R7] & $\begin{array}{l}\text { if } \mathrm{BB} / \mathrm{U} \text { Normal and } \mathrm{TB} / \mathrm{U} \text { Pendek and BB/TB Normal } \\
\text { then }\end{array}$ & Nelson & 0 & $\begin{array}{l}\text { Kecukupan Diit } \\
\text { Protein }\end{array}$ \\
\hline [R8] & $\begin{array}{l}\text { if } \mathrm{BB} / \mathrm{U} \text { Normal and } \mathrm{TB} / \mathrm{U} \text { Sangat Pendek and } \mathrm{BB} / \mathrm{TB} \\
\text { Gemuk then }\end{array}$ & Nelson & 0 & $\begin{array}{l}\text { Kecukupan Diit } \\
\text { Protein }\end{array}$ \\
\hline [R9] & $\begin{array}{l}\text { if } \mathrm{BB} / \mathrm{U} \text { Normal and } \mathrm{TB} / \mathrm{U} \text { Sangat Pendek and } \mathrm{BB} / \mathrm{TB} \\
\text { Normal then }\end{array}$ & Nelson & 0 & $\begin{array}{l}\text { Kecukupan Diit } \\
\text { Protein }\end{array}$ \\
\hline [R10] & $\begin{array}{l}\text { if BB/U Rendah and TB/U Jangkung and BB/TB Sangat } \\
\text { Kurus then }\end{array}$ & Nelson & $40 \%$ & $\begin{array}{l}\text { Kecukupan Diit } \\
\text { Protein }\end{array}$ \\
\hline [R11] & $\begin{array}{l}\text { if } \mathrm{BB} / \mathrm{U} \text { Rendah and } \mathrm{TB} / \mathrm{U} \text { Normal and BB/TB Kurus } \\
\text { then }\end{array}$ & Nelson & $20 \%$ & $\begin{array}{l}\text { Kecukupan Diit } \\
\text { Protein }\end{array}$ \\
\hline [R12] & $\begin{array}{l}\text { if } \mathrm{BB} / \mathrm{U} \text { Rendah and } \mathrm{TB} / \mathrm{U} \text { Pendek and BB/TB Normal } \\
\text { then }\end{array}$ & Nelson & $20 \%$ & $\begin{array}{l}\text { Kecukupan Diit } \\
\text { Protein }\end{array}$ \\
\hline [R13] & $\begin{array}{l}\text { if } \mathrm{BB} / \mathrm{U} \text { Rendah and } \mathrm{TB} / \mathrm{U} \text { Pendek and } \mathrm{BB} / \mathrm{TB} \text { Kurus } \\
\text { then }\end{array}$ & Nelson & $30 \%$ & $\begin{array}{l}\text { Kecukupan Diit } \\
\text { Protein }\end{array}$ \\
\hline [R14] & $\begin{array}{l}\text { if } \mathrm{BB} / \mathrm{U} \text { Rendah and } \mathrm{TB} / \mathrm{U} \text { Sangat Pendek and } \mathrm{BB} / \mathrm{TB} \\
\text { Normal then }\end{array}$ & Nelson & $30 \%$ & $\begin{array}{l}\text { Kecukupan Diit } \\
\text { Protein }\end{array}$ \\
\hline [R15] & $\begin{array}{l}\text { if BB/U Sangat Rendah and TB/U Jangkung and BB/TB } \\
\text { Sangat Kurus then }\end{array}$ & Nelson & $40 \%$ & $\begin{array}{l}\text { Kecukupan } \\
\text { KKP Protein }\end{array}$ \\
\hline [R16] & $\begin{array}{l}\text { if } \mathrm{BB} / \mathrm{U} \text { Sangat Rendah and } \mathrm{TB} / \mathrm{U} \text { Normal and } \mathrm{BB} / \mathrm{TB} \\
\text { Sangat Kurus then }\end{array}$ & Nelson & $30 \%$ & $\begin{array}{l}\text { Kecukupan } \\
\text { KKP Protein }\end{array}$ \\
\hline [R17] & $\begin{array}{l}\text { if } \mathrm{BB} / \mathrm{U} \text { Sangat Rendah and } \mathrm{TB} / \mathrm{U} \text { Pendek and } \mathrm{BB} / \mathrm{TB} \\
\text { Kurus then }\end{array}$ & Nelson & $40 \%$ & $\begin{array}{l}\text { Kecukupan } \\
\text { KKP Protein }\end{array}$ \\
\hline [R18] & $\begin{array}{l}\text { if BB/U Sangat Rendah and TB/U Sangat Pendek and } \\
\text { BB/TB Normal then }\end{array}$ & Nelson & $30 \%$ & $\begin{array}{l}\text { Kecukupan Diit } \\
\text { Protein }\end{array}$ \\
\hline [R19] & $\begin{array}{l}\text { if BB/U Sangat Rendah and TB/U Sangat Pendek and } \\
\text { BB/TB Kurus then }\end{array}$ & Nelson & $40 \%$ & $\begin{array}{l}\text { Kecukupan } \\
\text { KKP Protein }\end{array}$ \\
\hline
\end{tabular}

\subsection{Activity Diagram}

Dalam menentukan kebutuhan balita terhadap energi dan protein, input yang digunakan meliputi jenis kelamin, umur, berat badan dan tinggi badan. Keempat input tersebut digunakan untuk mengetahui status gizi balita serta menentukan kebutuhan energi dan protein yang sesuai dengan status gizinya. Proses yang terjadi dalam menentukan kebutuhan energi dan protein dapat dilihat pada Gambar 4.

Apabila data yang dimasukkan terdapat dalam database maka sistem akan menghitung z-score dari $\mathrm{BB} / \mathrm{U}, \mathrm{TB} / \mathrm{U}$, $\mathrm{BB} / \mathrm{TB}$. Kemudian sistem akan melakukan proses fuzzifikasi, inferensi, komposisi dan defuzzifikasi. Hasil dari proses tersebut yaitu kebutuhan energi, protein, lemak dan karbohidrat balita.

\section{PENGUJIAN DAN ANALISA}

Pengujian dilakukan agar perangkat lunak yang dibuat dapat menentukan kebutuhan energi dan protein sesuai dengan status gizi balita. Pengujian perangkat lunak dilakukan terhadap 50 data balita berusia 3659 bulan dengan membandingkan hasil metode fuzzy sugeno dan hasil metode manual terhadap kebutuhan energi dan protein yang dihasilkan dari standar ideal. 
Pengujian yang dilakukan terhadap kebutuhan energi dan protein akan bernilai benar jika selisih antara metode fuzzy sugeno atau metode manual terhadap standar ideal memenuhi batas atas dan bawah. Batas atas dan bawah yang merupakan hasil statistika inferensia dengan menggunakan selang kepercayaan $95 \%$ terhadap 50 data balita yang di uji coba dapat dilihat pada Tabel 6 dan Tabel 7. Sedangkan analisis kebenaran terhadap standar ideal berdasarkan batas atas dan bawah dapat dilihat pada Tabel 8 dan Tabel 9.

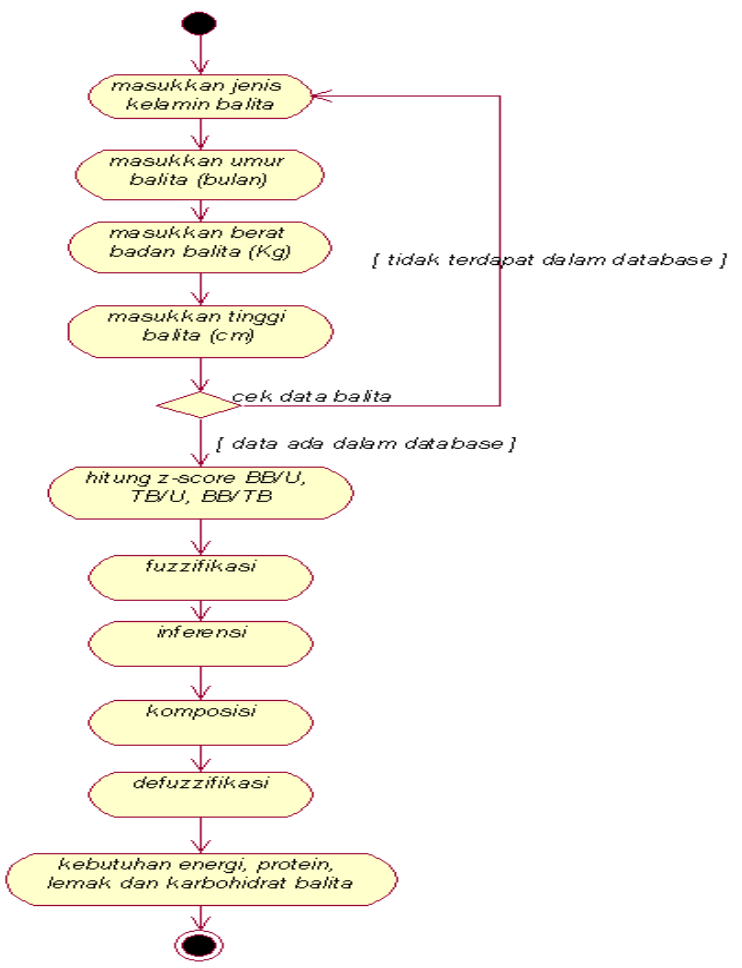

Gambar 4. Activity Diagram Hitung Kebutuhan Gizi Balita

Tabel 6. Batas atas dan bawah dalam uji coba kebutuhan energi

\begin{tabular}{|l|c|c|}
\hline Selisih & $\begin{array}{c}\text { Metode } \\
\text { Manual dan } \\
\text { Standar Ideal }\end{array}$ & $\begin{array}{c}\text { Metode Fuzzy } \\
\text { Sugeno dan } \\
\text { Standar Ideal }\end{array}$ \\
\hline Batas Atas & -132.53 & 9.74 \\
\hline $\begin{array}{l}\text { Batas } \\
\text { Bawah }\end{array}$ & 258.99 & -46.54 \\
\hline
\end{tabular}

Tabel 7. Batas atas dan bawah dalam uji coba kebutuhan protein

\begin{tabular}{|l|c|c|}
\hline Selisih & $\begin{array}{c}\text { Metode } \\
\text { Manual dan } \\
\text { Btandar Ideal }\end{array}$ & $\begin{array}{c}\text { Metode Fuzzy } \\
\text { Sugeno dan } \\
\text { Standar Ideal }\end{array}$ \\
\hline Batas Atas & -2.38 & 0.99 \\
\hline $\begin{array}{l}\text { Batas } \\
\text { Bawah }\end{array}$ & -5.12 & -0.49 \\
\hline
\end{tabular}

1. Analisis kebenaran metode fuzzy sugeno terhadap standar ideal

Prosentase kebutuhan energi

$=($ nilai benar $/$ jumlah data $) \times 100 \%$

$=(29 / 50) \times 100 \%$

$=58 \%$

Prosentase kebutuhan protein

$=($ nilai benar $/$ jumlah data $) \times 100 \%$

$=(43 / 50) \times 100 \%$

$=86 \%$

2. Analisis kebenaran metode manual terhadap standar ideal

Prosentase kebutuhan energi

$=$ (nilai benar / jumlah data) $\mathrm{x} 100 \%$

$=(12 / 50) \times 100 \%$

$=24 \%$

Prosentase kebutuhan protein

$=$ (nilai benar / jumlah data) $\mathrm{x} 100 \%$

$=(17 / 50) \times 100 \%$

$=34 \%$

Analisis kebenaran dalam menentukan kebutuhan energi dan protein yang dihasilkan metode fuzzy sugeno memiliki prosentase yang lebih besar yaitu 58\% untuk kebutuhan energi dan $86 \%$ untuk kebutuhan protein. Hal ini disebabkan indikator dalam menentukan status gizi pada metode manual adalah berat badan menurut umur, sehingga kebutuhan energi dan protein yang dihasilkan berdasarkan berat badan balita. Sedangkan indikator yang digunakan dalam metode fuzzy sugeno yaitu berat badan menurut umur, tinggi badan menurut umur dan berat badan menurut tinggi badan, sehingga kebutuhan energi dan protein yang dihasilkan berdasarkan berat badan dan tinggi badan balita. 
Tabel 8. Percobaan terhadap kebutuhan energi untuk 50 data balita

\begin{tabular}{|c|c|c|c|c|c|c|c|}
\hline \multirow[b]{2}{*}{ No. } & \multicolumn{3}{|c|}{ Kebutuhan Energi (KKal) } & \multirow{2}{*}{$\begin{array}{l}\text { Selisih } \\
\text { Metode } \\
\text { Manual } \\
\text { Denngan } \\
\text { Standar } \\
\text { Ideal } \\
\text { (X) }\end{array}$} & \multirow{2}{*}{$\begin{array}{c}\text { Selisih } \\
\text { Metode } \\
\text { Fuzzy } \\
\text { Sugeno } \\
\text { Denngan } \\
\text { Standar } \\
\text { Ideal (Y) }\end{array}$} & \multicolumn{2}{|c|}{$\begin{array}{c}\text { Analisis Kebenaran Terhadap } \\
\text { Standar Ideal Berdasarkan Batas } \\
\text { Atas Dan Batas Bawah } \\
\end{array}$} \\
\hline & $\begin{array}{l}\text { Standar } \\
\text { Ideal }\end{array}$ & $\begin{array}{l}\text { Metode } \\
\text { Manual }\end{array}$ & $\begin{array}{l}\text { Metode } \\
\text { Fuzzy } \\
\text { Sugeno }\end{array}$ & & & $\begin{array}{c}-258.99<X<- \\
132.53\end{array}$ & $\begin{array}{l}-46.54< \\
Y<9.74\end{array}$ \\
\hline 1. & 1460 & 1190 & 1418.32 & -270 & -41.68 & Salah & Benar \\
\hline 2. & 1460 & 1810 & 1594.69 & 350 & 134.69 & Salah & Salah \\
\hline 3. & 1480 & 1200 & 1443.30 & -280 & -36.70 & Salah & Benar \\
\hline 4. & 1480 & 1770 & 1551.20 & 290 & 71.20 & Salah & Salah \\
\hline 5. & 1500 & 1230 & 1453.03 & -270 & -46.97 & Salah & Salah \\
\hline 6. & 1500 & 1800 & 1533.14 & 300 & 33.14 & Salah & Salah \\
\hline 7. & 1580 & 1200 & 1551.52 & -380 & -28.48 & Salah & Benar \\
\hline 8. & 1600 & 1170 & 1546.64 & -430 & -53.36 & Salah & Salah \\
\hline 9. & 1620 & 1190 & 1567.12 & -430 & -52.88 & Salah & Salah \\
\hline 10. & 1530 & 1530 & 1530.00 & 0 & 0.00 & Salah & Benar \\
\hline 11. & 1548 & 1512 & 1541.57 & -36 & -6.43 & Salah & Benar \\
\hline 12. & 1566 & 1620 & 1510.15 & 54 & -55.85 & Salah & Salah \\
\hline 13. & 1566 & 1215 & 1510.89 & -351 & -55.11 & Salah & Salah \\
\hline 14. & 1566 & 1548 & 1562.74 & -18 & -3.26 & Salah & Benar \\
\hline 15. & 1575 & 1215 & 1530.33 & -360 & -44.67 & Salah & Benar \\
\hline 16. & 1593 & 1260 & 1536.1 & -333 & -56.9 & Salah & Salah \\
\hline 17. & 1611 & 1620 & 1612.53 & 9 & 1.53 & Salah & Benar \\
\hline 18. & 1620 & 1665 & 1626.57 & 45 & 6.57 & Salah & Benar \\
\hline 19. & 1638 & 1476 & 1613.97 & -162 & -24.03 & Benar & Benar \\
\hline 20. & 1638 & 1710 & 1650.65 & 72 & 12.65 & Salah & Salah \\
\hline 21. & 1638 & 1422 & 1551.69 & -216 & -86.31 & Benar & Salah \\
\hline 22. & 1647 & 1449 & 1603.35 & -198 & -43.65 & Benar & Benar \\
\hline 23. & 1647 & 1377 & 1610.35 & -270 & -36.65 & Salah & Benar \\
\hline 24. & 1665 & 1458 & 1616.08 & -207 & -48.92 & Benar & Salah \\
\hline 25. & 1665 & 1404 & 1629.19 & -261 & -35.81 & Salah & Benar \\
\hline 26. & 1410 & 980 & 1360.47 & -430 & -49.53 & Salah & Salah \\
\hline 27. & 1430 & 1010 & 1365.00 & -420 & -65.00 & Salah & Salah \\
\hline 28. & 1440 & 1030 & 1390.00 & -410 & -50.00 & Salah & Salah \\
\hline 29. & 1510 & 1270 & 1481.59 & -240 & -28.41 & Benar & Benar \\
\hline 30. & 1520 & 1310 & 1498.13 & -210 & -21.87 & Benar & Benar \\
\hline 31. & 1540 & 1280 & 1509.27 & -260 & -30.73 & Salah & Benar \\
\hline 32. & 1540 & 1300 & 1514.30 & -240 & -25.70 & Benar & Benar \\
\hline 33. & 1550 & 1330 & 1531.55 & -220 & -18.45 & Benar & Benar \\
\hline 34. & 1570 & 1230 & 1542.05 & -340 & -27.95 & Salah & Benar \\
\hline 35. & 1570 & 1210 & 1580.47 & -360 & 10.47 & Salah & Salah \\
\hline 36. & 1570 & 1370 & 1541.84 & -200 & -28.16 & Benar & Benar \\
\hline 37. & 1580 & 1190 & 1553.72 & -390 & -26.28 & Salah & Benar \\
\hline 38. & 1580 & 1240 & 1612.00 & -340 & 32.00 & Salah & Salah \\
\hline 39. & 1440 & 1062 & 1404.37 & -378 & -35.63 & Salah & Benar \\
\hline 40 & 1440 & 1107 & 1415.18 & -333 & -24.82 & Salah & Benar \\
\hline 41. & 1440 & 1125 & 1468.94 & -315 & 28.94 & Salah & Salah \\
\hline 42. & 1440 & 1080 & 1427.87 & -360 & -12.13 & Salah & Benar \\
\hline 43. & 1449 & 1152 & 1427.26 & -297 & -21.74 & Salah & Benar \\
\hline 44. & 1458 & 1179 & 1432.77 & -279 & -25.23 & Salah & Benar \\
\hline 45. & 1485 & 1287 & 1477.75 & -198 & -7.25 & Benar & Benar \\
\hline
\end{tabular}




\begin{tabular}{|r|r|r|r|r|r|r|r|}
\hline 46. & 1503 & 1296 & 1489.16 & -207 & -13.84 & Benar & Benar \\
\hline 47. & 1512 & 1287 & 1487.23 & -225 & -24.77 & Benar & Benar \\
\hline 48. & 1539 & 1602 & 1552.16 & 63 & 13.16 & Salah & Salah \\
\hline 49. & 1548 & 1620 & 1561.09 & 72 & 13.09 & Salah & Salah \\
\hline 50. & 1566 & 1647 & 1583.92 & 81 & 17.92 & Salah & Salah \\
\hline
\end{tabular}

Tabel 9. Percobaan terhadap kebutuhan protein untuk 50 data balita

\begin{tabular}{|c|c|c|c|c|c|c|c|}
\hline \multirow[t]{2}{*}{ No } & \multicolumn{3}{|c|}{ Kebutuhan Protein (gram) } & \multirow{2}{*}{$\begin{array}{c}\text { Selisih } \\
\text { Metode } \\
\text { Manual } \\
\text { Denngan } \\
\text { Standar } \\
\text { Ideal } \\
\text { (X) }\end{array}$} & \multirow{2}{*}{$\begin{array}{c}\text { Selisih } \\
\text { Metode } \\
\text { Fuzzy } \\
\text { Sugeno } \\
\text { Denngan } \\
\text { Standar } \\
\text { Ideal (Y) }\end{array}$} & \multicolumn{2}{|c|}{$\begin{array}{c}\text { Analisis Kebenaran Terhadap } \\
\text { Standar Ideal Berdasarkan Batas } \\
\text { Atas Dan Batas Bawah }\end{array}$} \\
\hline & $\begin{array}{c}\text { Standa } \\
\text { rIdeal }\end{array}$ & $\begin{array}{l}\text { Metode } \\
\text { Manual }\end{array}$ & $\begin{array}{c}\text { Metod } \\
\text { e } \\
\text { Fuzzy } \\
\text { Sugen } \\
\text { o } \\
\end{array}$ & & & $-5.12<X<-2.38$ & $-0.49<Y<0.99$ \\
\hline 1. & 26.86 & 21.89 & 26.86 & -4.97 & 0 & Benar & Benar \\
\hline 2. & 26.86 & 33.30 & 26.86 & 6.44 & 0 & Salah & Benar \\
\hline 3. & 27.23 & 22.10 & 27.23 & -5.13 & 0 & Salah & Benar \\
\hline 4. & 27.23 & 32.57 & 27.23 & 5.34 & 0 & Salah & Benar \\
\hline 5. & 27.60 & 22.63 & 27.60 & -4.97 & 0 & Benar & Benar \\
\hline 6. & 27.60 & 33.12 & 27.60 & 5.52 & 0 & Salah & Benar \\
\hline 7. & 29.07 & 22.10 & 29.66 & -6.97 & 0.59 & Salah & Benar \\
\hline 8. & 29.44 & 21.53 & 30.59 & -7.91 & 1.15 & Salah & Salah \\
\hline 9. & 29.81 & 21.89 & 30.92 & -7.92 & 1.11 & Salah & Salah \\
\hline 10. & 30.43 & 30.43 & 30.43 & 0 & 0 & Salah & Benar \\
\hline 11. & 30.79 & 30.10 & 30.79 & -0.69 & 0 & Benar & Benar \\
\hline 12. & 31.15 & 30.79 & 31.15 & -0.36 & 0 & Benar & Benar \\
\hline 13. & 31.15 & 32.22 & 31.15 & 1.07 & 0 & Salah & Benar \\
\hline 14. & 31.15 & 24.17 & 31.15 & -6.98 & 0 & Salah & Benar \\
\hline 15. & 31.33 & 24.17 & 31.33 & -7.16 & 0 & Salah & Benar \\
\hline 16. & 31.68 & 25.10 & 31.68 & -6.58 & 0 & Salah & Benar \\
\hline 17. & 32.04 & 32.22 & 32.04 & 0.18 & 0 & Salah & Benar \\
\hline 18. & 33.22 & 33.12 & 32.22 & -0.1 & -1 & Salah & Salah \\
\hline 19. & 32.58 & 29.36 & 32.58 & -3.22 & 0 & Benar & Benar \\
\hline 20. & 32.58 & 34.01 & 32.58 & 1.43 & 0 & Salah & Benar \\
\hline 21. & 32.58 & 28.28 & 32.58 & -4.3 & 0 & Benar & Benar \\
\hline 22. & 32.77 & 27.39 & 32.76 & -5.38 & -0.01 & Salah & Benar \\
\hline 23. & 32.76 & 28.82 & 32.76 & -3.94 & 0 & Benar & Benar \\
\hline 24. & 33.12 & 27.92 & 33.12 & -5.2 & 0 & Salah & Benar \\
\hline 25. & 33.12 & 28.99 & 33.12 & -4.13 & 0 & Benar & Benar \\
\hline 26. & 25.90 & 18.00 & 28.56 & -7.9 & 2.66 & Salah & Salah \\
\hline 27. & 26.30 & 18.58 & 28.13 & $\begin{array}{l}-7.72 \\
\end{array}$ & 1.83 & Salah & Salah \\
\hline 28. & 26.49 & 18.95 & 28.26 & $\begin{array}{l}-7.54 \\
\end{array}$ & 1.77 & Salah & Salah \\
\hline 29. & 27.78 & 23.37 & 27.78 & -4.41 & 0 & Benar & Benar \\
\hline 30. & 27.97 & 24.10 & 27.97 & -3.87 & 0 & Benar & Benar \\
\hline 31. & 28.34 & 23.55 & 28.34 & -4.79 & 0 & Benar & Benar \\
\hline 32. & 28.34 & 23.92 & 28.34 & -4.42 & 0 & Benar & Benar \\
\hline 33. & 28.52 & 24.47 & 28.52 & -4.05 & 0 & Benar & Benar \\
\hline 34. & 28.89 & 22.63 & 28.89 & -6.26 & 0 & Salah & Benar \\
\hline 35. & 28.89 & 25.21 & 28.89 & -3.68 & 0 & Benar & Benar \\
\hline 36. & 28.88 & 22.26 & 29.45 & -6.62 & 0.57 & Salah & Benar \\
\hline
\end{tabular}

61 


\begin{tabular}{|r|r|c|c|r|r|r|r|}
\hline 37. & 29.07 & 22.82 & 29.07 & -6.25 & 0 & Salah & Benar \\
\hline 38. & 29.07 & 21.89 & 29.92 & -7.18 & 0.85 & Salah & Benar \\
\hline 39. & 28.64 & 21.12 & 30.03 & -7.52 & 1.39 & Salah & Salah \\
\hline 40 & 28.64 & 22.38 & 28.86 & -6.26 & 0.22 & Salah & Benar \\
\hline 41. & 28.64 & 21.48 & 29.73 & -7.16 & 1.09 & Salah & Salah \\
\hline 42. & 28.64 & 22.00 & 29.14 & -6.64 & 0.5 & Salah & Benar \\
\hline 43. & 28.82 & 22.900 & 28.82 & -5.92 & 0 & Salah & Benar \\
\hline 44. & 28.99 & 23.45 & 28.99 & -5.54 & 0 & Salah & Benar \\
\hline 45. & 29.54 & 25.89 & 29.54 & -3.65 & 0 & Benar & Benar \\
\hline 46. & 29.89 & 25.77 & 29.89 & -4.12 & 0 & Benar & Benar \\
\hline 47. & 30.10 & 25.59 & 30.10 & -4.51 & 0 & Benar & Benar \\
\hline 48. & 30.61 & 31.86 & 30.61 & 1.25 & 0 & Salah & Benar \\
\hline 49. & 30.79 & 32.22 & 30.79 & 1.43 & 0 & Salah & Benar \\
\hline 50. & 31.15 & 32.76 & 31.15 & 1.61 & 0 & &
\end{tabular}

\section{KESIMPULAN DAN SARAN}

Pada penelitian yang dilakukan pada balita usia 36-59 bulan, metode fuzzy sugeno memiliki analisis kebenaran dengan standard ideal sebesar 58\% dalam menentukan kebutuhan energi. Sedangkan dalam menentukan kebutuhan protein, metode fuzzy sugeno memiliki analisis kebenaran dengan standard ideal sebesar $86 \%$. Nilai yang dihasilkan oleh fuzzy sugeno tersebut lebih mendekati kebutuhan ideal bila dibandingkan dengan metode manual yang memiliki analisis kebenaran dengan standard ideal sebesar $24 \%$ dalam menentukan kebutuhan energi. Sedangkan dalam menentukan kebutuhan protein, metode manual memiliki analisis kebenaran dengan standard ideal sebesar 34\%. Oleh karena itu, metode fuzzy sugeno dapat menjadi alternatif dalam menentukan kebutuhan energi dan protein sesuai dengan status gizi balita.

\section{DAFTAR PUSTAKA}

Anonim. Logika Fuzzy. www.Google. co.id/m?q =Logika\%20 fuzzy\% 20bentuk\%20ppt. Diakses tanggal 15 November 2009.
Ali. Arsad Rahim. 2008. Penilaian Status Gizi Anak. http://arali2008.files.word press.com /2008/08/penilaian-statusgizi-anak.doc. Diakses tanggal 20 Juli 2010

Almatsier. Sunita. 2004. Prinsip Dasar Ilmu Gizi. Jakarta : PT Gramedia Pustaka Umum

Depkes. RI. 2004. Analisis Situasi Gizi dan Kesehatan Masyarakat, Jakarta.

Kusumadewi, Sri. 2002. Analisis Desain Sistem Fuzzy Menggunakan Tool Box Matlab. Yogyakarta: Graha Ilmu

Kusumadewi. Sri dan Hari Purnomo. 2004. Aplikasi Logika Fuzzy Untuk Pendukung Keputusan. Yogyakarta: Graha Ilmu

Santoso, Soegeng dan Anne Lies. 1995. Kesehatan dan Gizi. Jakarta: Rineka Cipta 